\title{
EFEK SUPLEMENTASI MULTIVITAMIN MINERAL TERHADAP KADAR HEMOGLOBIN DAN HEMATOKRIT MAHASISWI TPB IPB
}

\author{
(The Effect of Multivitamin Mineral Supplementation to Hemoglobin and Hematocrit Concentration of \\ Bogor Agricultural University First Common Year Female Students)
}

Angga Hardiansyah ${ }^{1 *}$, Rimbawan ${ }^{1}$, dan Ikeu Ekayanti ${ }^{1}$

'Departemen Gizi Masyarakat, Fakultas Ekologi Manusia (FEMA), Institut Pertanian Bogor, Bogor 16680

\begin{abstract}
The objective of this study was to analyze effect of multivitamin mineral supplementation to hemoglobin and hematocrit concentration of Bogor Agricultural University First Common Year female students. Design of this study was the quasi experimental, double blind, with number of subjects were 28 female students devided into two group. The intervention group consisted of 15 subjects, received supplement syrup $15 \mathrm{ml}$ per day for eight weeks. The control group consisted of 13 subjects received placebo syrup. Data collected by interviewing subjects used questionnaire, physical examination, and blood biomarkers. The results of statistical test (paired sample t-test) showed that there were no significant increase in hemoglobin and hematocrit concentration respectively in both intervention and control groups ( $p>0.05)$. However, on a subset of subjects anemia, the hemoglobin and hematocrit in the intervention group tended to increase larger than the control group.
\end{abstract}

Keywords: anemia, female, hematocrit, hemoglobin, multivitamin mineral supplements

\begin{abstract}
ABSTRAK
Tujuan dari penelitian ini adalah untuk menganalisis efek suplementasi multivitamin mineral terhadap kadar hemoglobin dan hematokrit mahasiswi Tingkat Persiapan Bersama Institut Pertanian Bogor (TPB IPB). Penelitian ini menggunakan desain eksperimental semu, tersamar ganda, dengan jumlah subjek sebanyak 28 yang terbagi dalam dua kelompok. Kelompok intervensi terdiri dari 15 subjek, mendapatkan sirup suplemen $15 \mathrm{ml}$ setiap hari selama delapan minggu. Kelompok kontrol terdiri dari 13 subjek mendapatkan sirup plasebo. Data dikumpulkan dengan wawancara terhadap subjek menggunakan kuesioner, pemeriksaan fisik, dan pemeriksaan biokimia darah. Hasil uji statistik (paired sample t-test) menunjukkan tidak terdapat peningkatan yang nyata masing-masing kadar hemoglobin dan hematokrit baik pada kelompok intervensi maupun kontrol ( $>0.05)$. Namun, pada subset subjek yang anemia, peningkatan kadar hemoglobin dan hematokrit pada kelompok intervensi cenderung lebih besar dibandingkan pada kelompok kontrol.
\end{abstract}

Kata kunci: anemia, hematokrit, hemoglobin, mahasiswi, suplemen multivitamin mineral

"Korespondensi: Departemen Gizi Masyarakat, Fakultas Ekologi Manusia (FEMA), Institut Pertanian Bogor, Bogor 16680. Email: anggahardiansyah@gmail.com 
Hardiansyah dkk.

\section{PENDAHULUAN}

Permasalahan gizi mempunyai dampak negatif terhadap perkembangan sumberdaya manusia dan pembangunan nasional. Salah satu permasalahan gizi yang masih menjadi masalah kesehatan dunia adalah anemia. Prevalensi anemia di dunia cukup tinggi, terutama di negara yang sedang berkembang seperti indonesia. Menurut WHO (2008), prevalensi kejadian anemia di dunia antara tahun 1993 sampai 2005 sebanyak $24.8 \%$ dari total penduduk dunia. Penelitian yang dilakukan di berbagai wilayah indonesia menunjukkan prevalensi anemia pada semua kelompok umur bervariasi, yaitu 17.2-80.2\% (Angeles-Agdeppa et al. 1997 Soekarjo et al. 2004). Laporan hasil Riset Kesehatan Dasar (RISKESDAS) (2007) menyatakan bahwa prevalensi anemia pada tahun 2007 di Indonesia sebesar 11.9\%.

Remaja putri merupakan salah satu kelompok yang rentan mengalami anemia. Data nasional menunjukkan prevalensi anemia pada remaja sebesar 26.5-30\% (Depkes 2005). Studi yang dilakukan oleh Briawan (2008) pada mahasiswi Tingkat Persiapan Bersama IPB yang mendapatkan makanan tambahan dan suplementasi besi menunjukkan bahwa terdapat prevalensi anemia sebelum suplementasi sebesar $25.1 \%$ dan menurun menjadi $15.3 \%$ setelah suplementasi.

Anemia merupakan suatu kondisi akibat konsentrasi hemoglobin atau hematokrit yang lebih rendah dibandingkan batas normal. Anemia pada remaja mempunyai dampak negatif terhadap kesehatan, kemampuan belajar, dan produktivitas kerja (Haas \& Browlie 2001; WHO 2008). Salah satu penyebab utama anemia adalah defisiensi zat gizi dan sebagian besar anemia defisiensi zat gizi disebabkan oleh defisiensi besi. Akan tetapi, beberapa studi juga menyatakan bahwa defisiensi zat gizi mikro lainnya juga berperan dalam terjadinya anemia defisiensi zat gizi (Khatib et al. 2005; Ahmed et al. 2010).

Program perbaikan anemia sudah sering dilakukan dalam berbagai studi, salah satunya melalui suplementasi multvitamin mineral (Allen et al. 2002; Alarcon et al. 2004). Beberapa studi telah menunjukkan bahwa pemberian suplemen berupa multivitamin dan mineral mempunyai pengaruh positif dalam perbaikan status anemia (meningkatkan kadar hemoglobin) (Allen et al. 2000; Hyder et al. 2007; Gera et al. 2008). Sementara itu, studi yang dilakukan oleh Dwiriani (2012) menunjukkan bahwa suplementasi multivitamin mineral belum mampu meningkatkan kadar hemoglobin dan hematokrit remaja putri. Pemberian suplementasi multivitamin mineral dalam penelitian ini merupakan upaya peneliti untuk membuktikan efektivitas suplementasi multivitamin mineral terhadap perbaikan status anemia. Peneliti mencoba memperbaiki asupan zat gizi mikro mahasiswi yang konsumsi pangannya kurang baik. Penelitian ini bertujuan untuk mengidentifikasi karakteristik, kecukupan energi dan zat gizi, kadar hemoglobin, hematokrit, dan indeks sel darah merah, serta menganalisis efek suplementasi multivitamin mineral terhadap kadar hemoglobin dan hematokrit mahasiswi TPB IPB.

\section{METODE}

\section{Desain, Tempat, dan Waktu}

Desain penelitian ini adalah eksperimental semu, tersamar ganda, dengan dua kelompok perlakuan. Kelompok 1 (kelompok intervensi) mendapatkan suplementasi multivitamin mineral sedangkan kelompok 2 (kelompok kontrol) mendapatkan plasebo. Penelitian ini dilakukan di asrama Tingkat Persiapan Bersama (TPB) IPB selama enam bulan (2 bulan screening, 2 bulan suplementasi, dan 2 bulan analisis kandungan suplemen), mulai bulan AprilSeptember 2012. Analisis laboratorium dilaksanakan di Laboratorium Klinik Prodia Kota Bogor dan Laboratorium SIG (Saraswanti Indo Genetech).

\section{Jumlah dan Cara Penarikan Subjek}

Subjek dalam penelitian ini adalah mahasiswi TPB IPB yang telah diperiksa kadar Hbnya dengan metode cyanmethemoglobin, memenuhi kriteria inklusi dan eksklusi, serta bersedia mengikuti tahapan penelitian (menandatangani inform consent). Jumlah subjek minimal dihitung berdasarkan asumsi bahwa nilai $a=5 \%(Z a=1.645)$, kekuatan $u j i=80 \%(Z B=0.84)$, simpangan baku hemoglobin peubah respon $(\sigma=1.1$ $\mathrm{g} / \mathrm{dl}$ ) dan kenaikan nilai hemoglobin sebagai akibat pemberian suplemen multivitamin mineral $(\delta=1.1$ $\mathrm{g} / \mathrm{dl}$ ) (Ahmed et al. 2005). Jumlah subjek awal saat penelitian mulai dilaksanakan sebanyak 29 orang, yang terbagi atas 15 orang pada kelompok intervensi dan 14 orang pada kelompok kontrol. Selama suplementasi, satu orang pada kelompok kontrol dinyatakan drop out (DO) karena tidak mau melanjutkan tahapan-tahapan penelitian.

Suplemen multivitamin mineral (MVM) yang digunakan merupakan salah satu produk komersial yang dikemas dalam bentuk sirup. Suplemen MVM ini pada dasarnya bukan ditujukan untuk mengatasi anemia karena kandungan besi di dalamnya yang tidak terlalu tinggi dan hanya untuk melengkapi asupan besi dari makanan (kandungan besi glukonat MVM $20 \mathrm{mg}$ dan AKG besi sehari $26 \mathrm{mg}$ ). Namun, peneliti mencoba melihat efek suplemen tersebut terhadap peningkatan hemoglobin sebagai biomarker status anemia. Setiap subjek penelitian diinstruksikan untuk mengonsumsi sirup sebanyak $15 \mathrm{ml} / \mathrm{hari}$ sesuai takaran sajinya setiap pagi setelah sarapan selama delapan minggu. Rancangan kelompok perlakuan dan kandungan sirup suplemen disajikan pada Tabel 1. 
Tabel 1. Rancangan Kelompok Perlakuan dan Kandungan Suplemen

\begin{tabular}{|c|c|c|c|c|c|}
\hline Kelompok Perlakuan & Jenis Suplemen & Mikronutrien & Kandungan/15mL & AKG Sehari & $\%$ AKG \\
\hline \multirow[t]{10}{*}{ Intervensi } & Suplemen & Vitamin B1 & $15 \mathrm{mg}$ & $1.0 \mathrm{mg}$ & 1500 \\
\hline & Multivitamin & Vitamin B2 & $2.25 \mathrm{mg}$ & $1.1 \mathrm{mg}$ & 205 \\
\hline & Mineral & Vitamin B3 & $22.5 \mathrm{mg}$ & $14 \mathrm{mg}$ & 161 \\
\hline & & Vitamin B6 & $3 \mathrm{mg}$ & $1.3 \mathrm{mg}$ & 231 \\
\hline & & Vitamin B12 & $15 \mu \mathrm{g}$ & $2.4 \mu \mathrm{g}$ & 625 \\
\hline & & Vitamin C & $150 \mathrm{mg}$ & $75 \mathrm{mg}$ & 200 \\
\hline & & Besi (II) glukonat & $20 \mathrm{mg}$ & $26 \mathrm{mg}$ & 77 \\
\hline & & Kalsium glukonat & $100 \mathrm{mg}$ & $800 \mathrm{mg}$ & 13 \\
\hline & & Mangan sulfat & $2 \mathrm{mg}$ & $1.8 \mathrm{mg}$ & 111 \\
\hline & & Seng sulfat & $5 \mathrm{mg}$ & $9.3 \mathrm{mg}$ & 54 \\
\hline Kontrol & Plasebo & - & - & - & \\
\hline
\end{tabular}

\section{Jenis dan Cara Pengumpulan Data}

Data karakteristik subjek yang dikumpulkan sebelum suplementasi (baseline) meliputi tanggal lahir, pemasukan setiap bulan dan pengeluaran pangan. Data keadaan menstruasi subjek dikumpulkan selama suplementasi. Data tersebut dikumpulkan menggunakan kuesioner terstruktur. Data antropometri berupa tinggi dan berat badan dikumpulkan sebelum (baseline) dan setelah (endline) suplementasi. Data jumlah dan jenis pangan yang dikonsumsi diperoleh melalui pengisian kuesioner food record yang dilakukan oleh subjek dua kali setiap minggu (hari kuliah dan hari libur). Pengambilan darah dilakukan secara serentak sebelum dan setelah suplementasi oleh petugas Laboratorium Prodia di Asrama Putri TPB IPB. Status menstruasi tidak diperhatikan pada saat pengambilan darah. Akan tetapi, total hari menstruasi setiap subjek dilaporkan untuk melihat pengaruh menstruasi tersebut terhadap perubahan biomarker. Analisa kadar hemoglobin darah dilakukan oleh tenaga medis Laboratorium Prodia dengan menggunakan metode cyanmethemoglobin, sedangkan analisa kadar hematokrit $(\mathrm{Ht})$, Mean Cell Volume (MCV), Mean Cell Hemoglobin (MCH), Mean Cell Hemoglobin Concentration (MCHC) menggunakan metode Hematology mindray.

\section{Pengolahan dan Analisis Data}

Data konsumsi dari food record dikonversi ke dalam zat gizi menggunakan software Nutrisurvey yang diperkaya dengan bahan pangan dari database DKBM. Tingkat kecukupan energi dan protein subjek dihitung dengan membandingkan antara asupan energi dan protein dengan kebutuhan masing-masing subjek menggunakan formula perhitungan (WNPG 2004). Tingkat kecukupan zat gizi mikro subjek dihitung dengan membandingkan antara asupan zat gizi dengan angka kecukupan gizi (AKG) 2004 (WNPG 2004).

Uji statistik dilakukan untuk mengetahui perbedaan keragaman keseluruhan peubah antar kelompok perlakuan (baseline dan endline). Uji beda independent sample digunakan untuk membandingkan perbedaan peubah parametrik sebelum perlakuan seperti pemasukan bulanan, pengeluaran pangan, asupan dan tingkat kecukupan gizi, data antropometri, nilai $\mathrm{MCV}, \mathrm{MCH}, \mathrm{MCHC}$, hemoglobin, dan hematokrit. Uji paired-sample digunakan untuk membandingkan signifikansi peubah parametrik sebelum dan sesudah suplementasi.

\section{HASIL DAN PEMBAHASAN}

\section{Usia Subjek}

Subjek merupakan mahasiswi Tingkat Persiapan Bersama (mahasiswi tahun pertama) yang tinggal di asrama putri Institut Pertanian Bogor. Hasil penelitian menunjukkan bahwa rata-rata usia seluruh subjek $18.8 \pm 0.48$ tahun, dengan rincian $68.0 \%$ subjek berusia 18-18.9 tahun dan $32.0 \%$ berusia 19-20 tahun. Hasil penelitian ini sesuai dengan studi Briawan (2008) yang mengungkapkan sebagian besar (98.5\%) subjek mahasiswi TPB IPB berada dalam batasan remaja lanjut (late adolescene) yaitu antara 17-20 tahun.

\section{Uang Saku Bulanan Subjek}

Hasil penelitian menunjukkan bahwa $46.0 \%$ subjek memperoleh pemasukan bulanan dari orang tua, $29.0 \%$ dari beasiswa, $21.0 \%$ dari orang tua dan beasiswa, dan hanya $4.0 \%$ yang memperoleh pemasukan bulanan dari bekerja paruh waktu. Kisaran pemasukan bulanan seluruh subjek yaitu Rp 500 000-1 200000 dengan rata-rata sebesar Rp 737 $500 \pm 225924$. Rata-rata pemasukan bulanan subjek pada kelompok intervensi sebesar Rp 743 333 \pm 259 716 dan pada kelompok kontrol sebesar Rp 730 $769 \pm 189$ 889. Hasil analisis uji beda (independent sample t-test) menunjukkan bahwa tidak terdapat perbedaan yang nyata rata-rata pemasukan bulanan antar kelompok ( $p>0.05)$. 


\section{Pengeluaran Pangan Subjek}

Pengeluaran pangan terdiri dari pengeluaran untuk makanan, minuman, dan jajanan. Kisaran pengeluaran pangan seluruh subjek per bulan yaitu Rp 360 000-600 000 dengan rata-rata Rp $462857 \pm 95$ 687. Rata-rata subjek menghabiskan 63.3\% pemasukan bulanan untuk pengeluaran pangan. Rata-rata pengeluaran pangan subjek pada kelompok intervensi sebesar Rp 478 000 105438 dan pada kelompok kontrol sebesar Rp $445385 \pm 89033$. Berdasarkan uji beda, tidak terdapat perbedaan yang nyata rata-rata pengeluaran pangan antar kelompok $(p>0.05)$.

\section{Keadaan Menstruasi Subjek}

Seluruh subjek dalam penelitian ini adalah remaja putri yang berada dalam fase reproduktif dan mengalami menstruasi. Hasil penelitian menunjukkan usia pertama kali subjek mengalami menstruasi (menarche) berkisar antara 11-15 tahun dengan rata-rata usia menarche $13 \pm 1.4$ tahun. Rata-rata total hari menstruasi seluruh subjek selama suplementasi adalah $11.8 \pm 4.5$ hari. Rata-rata total hari menstruasi kelompok intervensi selama suplementasi cenderung lebih besar (12.6 \pm 5.3 hari) dibandingkan dengan kelompok kontrol $(10.8 \pm 3.0$ hari), meskipun berdasarkan uji beda, perbedaan tersebut tidak nyata $(p>0.05)$.

\section{Status Gizi Antropometri Subjek}

Pengukuran antropometri yang dilakukan pada penelitian ini meliputi pengukuran berat badan, tinggi badan, dan perhitungan nilai Indeks Massa Tubuh (IMT). Kisaran berat badan seluruh subjek sebelum suplementasi yaitu 42.7-69.5 kg dengan rata-rata sebesar $52.1 \pm 7.4 \mathrm{~kg}$. Hasil uji beda menunjukkan tidak terdapat perbedaan nyata ratarata berat badan subjek antar kelompok ( $p>0.05$ ).

Kisaran tinggi badan seluruh subjek sebelum suplementasi yaitu $140.5-163.1 \mathrm{~cm}$ dengan rata-rata sebesar $155.5 \pm 4.9 \mathrm{~cm}$. Hasil uji beda menunjukkan bahwa tidak terdapat perbedaan yang nyata ratarata tinggi badan subjek antar kelompok ( $p>0.05)$.

Kisaran nilai IMT seluruh subjek sebelum suplementasi yaitu $17.8-27.5 \mathrm{~kg} / \mathrm{m}^{2}$ dengan rata-rata sebesar $21.6 \pm 2.6 \mathrm{~kg} / \mathrm{m}^{2}$. Hasil uji beda menunjukkan terdapat perbedaan yang nyata rata-rata IMT subjek antar kelompok $(\mathrm{p}<0.05)$. Rata-rata IMT subjek pada kelompok intervensi lebih besar $\left(22.6 \pm 2.8 \mathrm{~kg} / \mathrm{m}^{2}\right)$ dibandingkan pada kelompok kontrol $(20.4 \pm 2.0 \mathrm{~kg} /$ $\mathrm{m}^{2}$ ). Meskipun terdapat perbedaan nyata nilai IMT antar kelompok, tetapi beberapa studi menyatakan kondisi tersebut tidak berpengaruh terhadap respon perubahan biomarker (hemoglobin dan hematokrit) (Ahmed et al. 2005; Briawan 2008).
Kadar Hemoglobin dan Hematokrit sebelum Suplementasi

Kadar $\mathrm{Hb}$ seluruh subjek sebelum suplementasi berkisar antara 8.9-13.2 g/dL dengan rata-rata $11.8 \pm 1.2 \mathrm{~g} / \mathrm{dL}$. Adapun kadar $\mathrm{Ht}$ subjek sebelum suplementasi berkisar antara $28.0-40.7 \%$ dengan rata-rata sebesar $36.4 \%$. Hasil uji beda menunjukkan tidak terdapat perbedaan nyata baik ratarata kadar $\mathrm{Hb}$ maupun kadar $\mathrm{Ht}$ antar kelompok ( $p>0.05$ ). Total subjek anemia berdasarkan indikator hemoglobin sebanyak $39.3 \%$, sedangkan subjek anemia berdasarkan kadar hematokrit sebanyak 35.7\%. Terdapat 3.6\% subjek $(\mathrm{n}=1)$ anemia berdasarkan $\mathrm{Hb}$ $(\mathrm{Hb}<12)$, tetapi normal berdasarkan kadar $\mathrm{Ht}(\mathrm{Ht}$ 236). Kondisi tersebut dikategorikan defisiensi besi tingkat sedang (Gibson 2005).

Nilai Indeks Sel Darah Merah sebelum Suplementasi

Nilai MCV subjek sebelum suplementasi berkisar antara 60.4-92.2 fl dengan rata-rata sebesar $80.8 \pm 8.7$ fl. Rata-rata nilai MCV kelompok intervensi sebesar $82.0 \pm 6.3 \mathrm{fl}$ dan pada kelompok kontrol sebesar $79.4 \pm 10.9 \mathrm{fl}$. Hasil uji beda menunjukkan tidak terdapat perbedaan nyata kadar MCV antar kelompok ( $p>0.05)$. Lebih dari separuh subjek (57.1\%) memiliki sel darah merah mikrositik, dan tidak terdapat subjek yang sel darah merahnya makrositik.

Nilai $\mathrm{MCH}$ subjek sebelum suplementasi berkisar antara 19.1-30.7 pg, dengan rata-rata sebesar $26.2 \pm 3.5 \mathrm{pg}$. Rata-rata nilai $\mathrm{MCH}$ kelompok intervensi sebesar $26.4 \pm 2.6 \mathrm{pg}$ dan pada kelompok kontrol sebesar $25.9 \pm 4.5 \mathrm{pg}$. Hasil uji beda menunjukkan tidak terdapat perbedaan nyata kadar $\mathrm{MCH}$ antar kelompok $(p>0.05)$. Hampir separuh subjek (46.4\%) mempunyai kadar MCH di bawah normal, dan tidak terdapat subjek dengan kadar $\mathrm{MCH}$ di atas normal.

Nilai MCHC subjek sebelum suplementasi berkisar antara $28.9-33.9 \%$, dengan rata-rata sebesar $32.9 \pm 1.3 \%$. Rata-rata nilai MCHC pada kelompok intervensi relatif sama $(32.1 \pm 1.0 \%)$ dengan kelompok kontrol $(32.4 \pm 1.6 \%)$. Hasil uji beda juga menunjukkan tidak terdapat perbedaan yang nyata rata-rata nilai MCHC antar kelompok ( $p>0.05)$. Sebagian besar subjek (64.3\%) mempunyai nilai MCHC dibawah normal (hipokromik) dan tidak terdapat subjek yang terkategori hiperkromik. Terdapat prevalensi anemia sebesar 39.3\% (berdasarkan $\mathrm{Hb}$ ), dan dari prevalensi tersebut $91.0 \%$ diantaranya merupakan jenis anemia mikrositik hipokromik yang lebih disebabkan oleh defisiensi besi. Gambaran ini hampir sama dengan laporan RISKESDAS (2007) yang menyatakan bahwa sekitar $60.0 \%$ anemia pada wanita dewasa adalah 
mikrositik hipokromik. Studi Dwiriani (2012) juga menyatakan bahwa sekitar separuh subjek dalam penelitiannya yang merupakan kelompok remaja putri menderita anemia mikrositik.

\section{Suplementasi Sirup Multivitamin Mineral}

Kepatuhan minum suplemen. Berdasarkan Briawan (2008), tingkat kepatuhan konsumsi suplemen dinyatakan tinggi apabila mencapai $80 \%$ dari konsumsi total. Kepatuhan konsumsi suplemen subjek dianalisis berdasarkan formulir yang dilaporkan sendiri oleh subjek (self reported) dan dengan pengukuran sisa suplemen. Hasil pemantauan formulir kepatuhan menunjukkan rata-rata seluruh subjek mempunyai tingkat kepatuhan $>80 \%$. Hasil ini berbeda dengan pemantauan tingkat kepatuhan hasil pengukuran sisa suplemen yaitu sebesar $61.6 \%$. Rata-rata subjek menjelaskan bahwa frekuensi konsumsi suplemen sudah sesuai dengan yang dituliskan di formulir kepatuhan, tetapi porsi takaran sirup seringkali tidak tepat (sering tidak penuh karena takut tumpah). Dari hasil tersebut, dapat disimpulkan bahwa rata-rata subjek mengonsumsi suplemen harian di bawah takaran saji $(15 \mathrm{ml})$.

Asupan dan tingkat kecukupan energi dan zat gizi. Rata-rata asupan energi dan zat gizi subjek selama suplementasi diperoleh dari hasil konversi data konsumsi pangan yang dilaporkan oleh subjek $2 \mathrm{kali} /$ minggu (hari kuliah dan hari libur) selama suplementasi. Hasil penelitian menunjukkan bahwa asupan energi, protein, vitamin A, B1, B6, asam folat, vitamin $C$, dan besi subjek pada kelompok intervensi dari makanan (tanpa suplemen) cenderung lebih rendah dibandingkan dengan kelompok kontrol. Adapun asupan seng subjek pada kelompok intervensi cenderung lebih tinggi dibandingkan dengan kelompok kontrol. Akan tetapi, perbedaan tersebut tidak nyata berdasarkan uji beda $(p>0.05)$. Asupan energi dan zat gizi subjek disajikan pada Tabel 2.

Jika dilihat dari tingkat kecukupan gizi (TKG), rata-rata tingkat kecukupan energi subjek masih rendah dan masuk dalam kategori defisit sedang (70-79.9\%AKG). Rata-rata tingkat kecukupan zat gizi mikro (tanpa suplemen) subjek masih rendah dan masuk dalam kategori defisit ( $<77 \%$ AKG). Hanya rata-rata asupan protein dan vitamin A subjek yang mencukupi kebutuhan (protein $>90 \%$ AKG dan vitamin $A>77 \% A K G$ ). Tingkat kecukupan energi dan zat gizi subjek disajikan pada Tabel 3.

Hasil ini sesuai dengan studi Briawan (2008) yang menyatakan bahwa sekitar $80.0 \%$ subjek penelitiannya yang merupakan mahasiswi TPB IPB mengalami defisit berat energi, $85.0 \%$ subjek mengalami defisit besi, dan sekitar $60.0 \%$ mengalami defisit vitamin C. Dwiriani (2012) melaporkan hal yang sama, yaitu lebih dari $60.0 \%$ subjek penelitiannya yang merupakan remaja putri mengalami defisit energi tingkat berat, $80.0 \%$ subjek mengalami defisit besi dan vitamin C. Jika asupan zat gizi mikro dari suplemen diperhatikan, rata-rata tingkat kecukupan vitamin B1, vitamin B2, vitamin B6, vitamin C dan seng subjek sudah mencukupi kebutuhan $(>77 \%)$. Asupan dari suplemen berbeda antar subjek, tergantung tingkat kepatuhan subjek dalam konsumsi suplemen (kepatuhan berdasarkan sisa suplemen). Hanya asupan asam folat dan besi subjek yang belum mencukupi kebutuhan. Berdasarkan data tersebut, nampaknya pemberian suplemen multivitamin mineral ini memang perlu dilakukan.

Efek Suplementasi terhadap Kadar Hemoglobin dan Hematokrit. Rata-rata peningkatan kadar hemoglobin $(\Delta \mathrm{Hb})$ seluruh subjek (rata-rata $\Delta$ $\mathrm{Hb}$ kelompok kontrol + intervensi) sebesar $0.2 \mathrm{~g} /$ $\mathrm{dL}$ Rata-rata peningkatan kadar hemoglobin $(\Delta \mathrm{Hb})$

Tabel 2. Rata-rata Asupan Energi dan Zat Gizi menurut Kelompok Selama Suplementasi

\begin{tabular}{|c|c|c|c|c|}
\hline \multirow{3}{*}{ Zat gizi } & \multicolumn{3}{|c|}{ Asupan } & \multirow{3}{*}{$\mathrm{p}$} \\
\hline & \multirow{2}{*}{ Kontrol } & \multicolumn{2}{|c|}{ Intervensi } & \\
\hline & & (-) Suplemen & (+) Suplemen & \\
\hline Energi (kkal) & $1610 \pm 197^{a}$ & $1513 \pm 212^{a}$ & $1513 \pm 212$ & 0.105 \\
\hline Protein (g) & $48.6 \pm 5.3 a$ & $46.8 \pm 6.5^{\text {a }}$ & $46.8 \pm 6.5$ & 0.722 \\
\hline Vit A $(\mu g)$ & $1394.8 \pm 339.0^{\text {a }}$ & $1207.1 \pm 275^{a}$ & $1207.1 \pm 275$ & 0.158 \\
\hline Vit B1 (mg) & $0.5 \pm 0.1$ a & $0.4 \pm 0.1^{a}$ & $9.6 \pm 2.0$ & 0.424 \\
\hline Vit B2 (mg) & $0.8 \pm 0.1^{a}$ & $0.7 \pm 0.2^{\mathrm{a}}$ & $2.1 \pm 0.2$ & 0.642 \\
\hline Vit B6 (mg) & $0.9 \pm 0.1$ a & $0.8 \pm 0.2^{a}$ & $2.6 \pm 0.2$ & 0.424 \\
\hline Asam folat $(\mu \mathrm{g})$ & $123.7 \pm 19.7$ a & $116.8 \pm 30.1^{a}$ & $116.8 \pm 30.1$ & 0.596 \\
\hline Vit C (mg) & $41.9 \pm 14.6^{a}$ & $41.6 \pm 26.4^{\mathrm{a}}$ & $133.4 \pm 29$ & 0.452 \\
\hline Besi (mg) & $6.9 \pm 1.2$ a & $6.4 \pm 1.1$ a & $18.7 \pm 1.1$ & 0.174 \\
\hline Seng (mg) & $5.6 \pm 0.7$ a & $5.3 \pm 0.8$ & $8.3 \pm 1.0$ & 0.461 \\
\hline
\end{tabular}


Tabel 3. Rata-rata Tingkat Kecukupan Energi dan Zat Gizi menurut Kelompok selama Suplementasi

\begin{tabular}{|c|c|c|c|c|}
\hline \multirow{3}{*}{ Zat gizi (\%) } & \multicolumn{3}{|c|}{ Tingkat Kecukupan Gizi } & \multirow{3}{*}{$\mathrm{p}$} \\
\hline & \multirow{2}{*}{ Kontrol } & \multicolumn{2}{|r|}{ Intervensi } & \\
\hline & & (-) Suplemen & (+) Suplemen (9.2 ml/hari) & \\
\hline Energi & $77^{a}$ & $70^{a}$ & 70 & 0.221 \\
\hline Protein & $102^{a}$ & $92^{\mathrm{a}}$ & 92 & 0.157 \\
\hline Vit A & $231^{a}$ & $211^{a}$ & 211 & 0.266 \\
\hline Vit B1 & $44^{\mathrm{a}}$ & $42^{a}$ & 800 & 0.541 \\
\hline Vit B2 & $74^{\mathrm{a}}$ & $69^{a}$ & 201 & 0.443 \\
\hline Vit B6 & $70^{a}$ & $66^{a}$ & 214 & 0.541 \\
\hline Asam folat & $31^{\mathrm{a}}$ & 29 a & 28 & 0.540 \\
\hline Vit C & $56^{a}$ & $55^{a}$ & 178 & 0.448 \\
\hline Besi & $27^{a}$ & $25^{a}$ & 72 & 0.187 \\
\hline Seng & $45^{\mathrm{a}}$ & $46^{\mathrm{a}}$ & 72 & 0.708 \\
\hline
\end{tabular}

Keterangan:

a Pada baris yang sama, angka dengan huruf sama menunjukkan tidak terdapat perbedaan yang nyata antar kelompok ( $p>0.05)$

seluruh subjek sebesar $0.2 \mathrm{~g} / \mathrm{dL}$. Rata-rata peningkatan kadar $\mathrm{Hb}$ pada kelompok intervensi sebesar $0.1 \mathrm{~g} / \mathrm{dL}$ dan pada kelompok kontrol sebesar $0.2 \mathrm{~g} /$ $\mathrm{dL}$ (Tabel 4). Hasil uji beda menunjukkan tidak terdapat perbedaan nyata rata-rata peningkatan kadar $\mathrm{Hb}$ antar kelompok ( $\mathrm{p}>0.05)$. Hasil uji paired sample menunjukkan tidak terjadi peningkatan nyata kadar $\mathrm{Hb}$ pada kedua kelompok ( $\mathrm{p}>0.05)$.

Jika dilihat pada subset subjek yang anemia (anemia sedang dan ringan), rata-rata peningkatan kadar $\mathrm{Hb}$ pada kelompok intervensi 5 kali lebih besar $(0.5 \mathrm{~g} / \mathrm{dL})$ dibandingkan dengan kelompok kontrol $(0.1 \mathrm{~g} / \mathrm{dL})$, meskipun hasil uji beda menunjukkan perbedaan tersebut tidak nyata $(p>0.05)$. Uji paired sample juga menunjukkan tidak terjadi peningkatan nyata kadar $\mathrm{Hb}$ pada kedua kelompok setelah suplementasi ( $p>0.05$ ). Kadar hemoglobin sebelum dan setelah suplementasi disajikan pada Tabel 4.

Setelah suplementasi, rata-rata kadar Ht subjek juga mengalami peningkatan. Rata-rata peningkatan kadar $\mathrm{Ht}(\Delta \mathrm{Ht})$ seluruh subjek (rata-rata sebesar $\Delta \mathrm{Ht}$ kelompok kontrol + intervensi) sebesar $0.8 \pm 1.8 \%$. Rata-rata peningkatan kadar $\mathrm{Ht}$ pada kelompok intervensi sebesar $0.7 \%$ dan pada kelompok kontrol sebesar 1.0\%. Berdasarkan uji beda, perbedaan rata-rata peningkatan kadar $\mathrm{Ht}$ antar kelompok tidak nyata $(\mathrm{p}>0.05)$. Uji paired sample juga menunjukkan tidak terjadi peningkatan yang nyata kadar $\mathrm{Ht}$ setelah suplementasi pada kedua kelompok $(p>0.05)$.

Tabel 4. Rata-rata Kadar Hb menurut Kelompok Perlakuan Sebelum dan Setelah Suplementasi

\begin{tabular}{lcccc}
\hline \multirow{2}{*}{ Profil darah } & Waktu & \multicolumn{2}{c}{ Kelompok } & \multirow{2}{*}{ P } \\
\cline { 3 - 4 } & & Kontrol & Intervensi & \\
\hline Subjek total: & Sebelum & $11.7 \pm 1.4^{\text {a }}$ & $11.9 \pm 1.2^{\text {a }}$ & 0.509 \\
$\mathrm{Hb}(\mathrm{g} / \mathrm{dL})$ & Setelah & $11.8 \pm 1.6^{\mathrm{a}}$ & $12.0 \pm 0.1^{\mathrm{a}}$ & 0.935 \\
& Selisih & $0.2 \pm 0.6^{\mathrm{a}}$ & $0.1 \pm 0.6^{\mathrm{a}}$ & 0.721 \\
Subjek anemia: & Sebelum & $10.3 \pm 0.9^{\mathrm{a}}$ & $10.5 \pm 1.1^{\mathrm{a}}$ & 0.761 \\
$\mathrm{Hb}(\mathrm{g} / \mathrm{dL})$ & Setelah & $10.4 \pm 1.2^{\mathrm{a}}$ & $11.0 \pm 0.9^{\text {a }}$ & 0.402 \\
& Selisih & $0.1 \pm 0.6^{\mathrm{a}}$ & $0.5 \pm 0.4^{\mathrm{a}}$ & 0.257 \\
Subjek tidak anemia: & Sebelum & $12.6 \pm 0.4^{\mathrm{a}}$ & $12.6 \pm 0.4^{\mathrm{a}}$ & 0.791 \\
$\mathrm{Hb}(\mathrm{g} / \mathrm{dL})$ & Setelah & $13.0 \pm 0.6^{\mathrm{a}}$ & $12.6 \pm 0.6^{\mathrm{a}}$ & 0.172 \\
& Selisih & $0.3 \pm 0.6^{\mathrm{a}}$ & $0.0 \pm 0.6^{\mathrm{a}}$ & 0.225 \\
\hline
\end{tabular}

Keterangan:

a Pada baris yang sama, angka dengan huruf sama menunjukkan tidak terdapat perbedaan yang nyata antar kelompok $(p>0.05)$ 
Tabel 5. Rata-rata Kadar Ht menurut Kelompok Perlakuan Sebelum dan Setelah Suplementasi

\begin{tabular}{lcccc}
\hline \multirow{2}{*}{ Profil darah } & Waktu & \multicolumn{2}{c}{ Kelompok } & \multirow{2}{*}{ p } \\
\cline { 3 - 4 } & & Kontrol & Intervensi & \\
\hline Subjek total: & Sebelum & $35.7 \pm 3.2^{\mathrm{a}}$ & $37.0 \pm 2.8^{\mathrm{a}}$ & 0.239 \\
Ht (\%) & Setelah & $36.6 \pm 3.7^{\mathrm{a}}$ & $37.7 \pm 2.2^{\mathrm{a}}$ & 0.332 \\
& Selisih & $1.0 \pm 1.9^{\mathrm{a}}$ & $0.7 \pm 1.7^{\mathrm{a}}$ & 0.598 \\
Subjek anemia: & Sebelum & $33.2 \pm 2.8^{\mathrm{a}}$ & $33.8 \pm 2.4^{\mathrm{a}}$ & 0.696 \\
Ht (\%) & Setelah & $33.7 \pm 0.6^{\mathrm{a}}$ & $36.0 \pm 1.9^{\mathrm{a} .1}$ & 0.216 \\
& Selisih & $0.5 \pm 1.9^{\mathrm{a}}$ & $2.2 \pm 0.9^{\mathrm{a}}$ & 0.115 \\
Subjek tidak anemia: & Sebelum & $37.8 \pm 1.4^{\mathrm{a}}$ & $38.6 \pm 1.0^{\mathrm{a}}$ & 0.168 \\
Ht (\%) & Setelah & $39.1 \pm 1.4^{\mathrm{a}}$ & $38.6 \pm 1.8^{\mathrm{a}}$ & 0.549 \\
& Selisih & $1.3 \pm 2.0^{\mathrm{a}}$ & $0.0 \pm 1.5^{\mathrm{a}}$ & 0.143 \\
\hline
\end{tabular}

Keterangan:

a Pada baris yang sama, angka dengan huruf sama menunjukkan tidak terdapat perbedaan yang nyata antar kelompok $(p>0.05)$

${ }^{1}$ Pada kelompok yang sama terdapat perbedaan yang nyata $(P<0.05)$ sebelum dan sesudah suplementasi (Uji beda paired sampe t-test)

Jika dilihat pada subset subjek yang anemia, rata-rata peningkatan kadar $\mathrm{Ht}$ pada kelompok intervensi 4 kali lebih besar (2.2\%) dibandingkan dengan kelompok kontrol (0.5\%). Hasil uji beda menunjukkan perbedaan tersebut tidak nyata ( $p>0.05)$. Uji paired sample menunjukkan terjadi peningkatan nyata kadar $\mathrm{Ht}$ setelah suplementasi pada kelompok intervensi $(p<0.05)$ dan tidak terjadi peningkatan nyata pada kelompok kontrol ( $p>0.05)$. Kadar Ht sebelum dan setelah suplementasi disajikan pada Tabel 5.

Program suplementasi besi di berbagai negara memang tidak selalu menunjukkan hasil yang efektif. Hasil penelitian ini menunjukkan bahwa suplementasi multivitamin mineral yang diberikan secara harian selama 8 minggu belum mampu meningkatkan kadar $\mathrm{Hb}$ dan $\mathrm{Ht}$ subjek secara nyata $(p>0.05)$. Belum berhasilnya suplementasi diduga disebabkan oleh berbagai hal, antara lain 1) rendahnya kepatuhan konsumsi suplemen (dalam hal volume takaran saji) (Briawan 2008; Soekarjo et al. 2004), 2) tidak mencukupinya dosis zat besi suplemen dalam mencukupi kebutuhan (Depkes 2005; WNPG 2004; Zavaleta et al. 2000) , 3) durasi kegiatan suplementasi yang relatif singkat $(8$ minggu) (Tee et al. 1999; Kanani \& Poojara 2000; Ahmed et al. 2005; Hyder et al. 2007; Marcia et al. 2010 ) , dan 4) kondisi sampel yang sebagian besar tidak anemia (Ahmed et al. 2005; Briawan 2008; Dwiriani 2012).

\section{KESIMPULAN}

Seluruh subjek dalam penelitian ini masuk dalam kategori remaja lanjut (17-20 tahun). Hasil uji statistik menunjukkan tidak terdapat perbedaan nyata baik pendapatan bulanan, pengeluaran pangan, total hari menstruasi, dan berat badan antar kelompok ( $>0.05)$. Akan tetapi, terdapat perbedaan nyata IMT antar kelompok $(p<0.05)$. Asupan energi hampir separuh subjek (42.9\%) dalam kategori defisit berat (<70\% AKG) dan hanya 10.7\% subjek yang asupan energinya terpenuhi (90-110\%). Asupan protein sebagian besar subjek (53.6\%) sudah terpenuhi, dan tidak ada subjek yang asupannya dibawah $70 \% A K G$. Asupan zat gizi mikro subjek dari makanan secara keseluruhan masih rendah, hanya asupan vitamin A yang sudah mencukupi kebutuhan (>77\%AKG).

Hasil uji beda menunjukkan tidak terdapat perbedaan nyata kadar $\mathrm{Hb}$ dan $\mathrm{Ht}$ antar kelompok sebelum suplementasi ( $p>0.05)$. Prevalensi anemia pada subjek (berdasarkan $\mathrm{Hb}$ ) sebesar 39.3\% dan $91.0 \%$. Secara umum suplementasi multivitamin mineral tidak meningkatkan kadar $\mathrm{Hb}$ seluruh subjek secara nyata $(p>0.05)$. Pada subset subjek yang anemia, rata-rata peningkatan kadar $\mathrm{Hb}$ cenderung lebih besar pada kelompok intervensi dibandingkan dengan kelompok kontrol. Suplementasi multivitamin mineral juga tidak meningkatkan kadar $\mathrm{Ht}$ seluruh subjek secara nyata $(p>0.05)$. Pada subset subjek yang anemia, rata-rata peningkatan kadar $\mathrm{Ht}$ lebih besar pada kelompok intervensi dibandingkan dengan kelompok kontrol. Suplemen yang digunakan merupakan salah satu produk komersial. Hasil penelitian menunjukkan bahwa subjek merasa kesulitan dalam menakar sirup suplemen dengan tepat. Oleh karena itu, pengadaan sendok takar dengan kapasitas volume $15 \mathrm{ml}$ perlu dipertimbangkan oleh produsen sehingga konsumsi sirup dapat dilakukan dengan tepat dalam satu kali takaran. Kandungan besi di dalam suplemen juga perlu ditingkatkan sehingga dalam satu takaran saji suplemen tersebut mampu memenuhi AKG besi sehari atau mengacu pada stan- 
dar WHO yang mengandung $60 \mathrm{mg}$ besi elemental. Semua subjek yang mengikuti kegiatan suplementasi sebaiknya dalam kondisi homogen anemia dan durasi suplementasi juga perlu diperpanjang agar respon peningkatan kadar $\mathrm{Hb}$ dan $\mathrm{Ht}$ lebih terlihat.

\section{DAFTAR PUSTAKA}

Ahmed F et al. 2005. Efficacy of twice weekly multiple micronutrient supplementation for improving the hemoglobin and micronutrient status of anemia adolescent girl in Bangladesh. Am J Clin Nutr 82, 829-835.

. 2010. Long-term intermittent multiple micronutrient supplementation enhances hemoglobin and micronutrient status more than Iron+folic acid supplementation in Bangladeshi rural adolescent girls with nutritional anemia. J Nutr 140, 1879-1886.

Alarcon $\mathrm{K}$ et al. 2004. Effects of separate delivery of zinc or zinc and vitamin A on hemoglobin response, growth, and diarrhea in young Peruvian children receiving iron therapy for anemia. Am J Clin Nutr 80, 1276-1282.

Allen LH et al. 2000. Lack of hemoglobin response to iron supplementation in anemic Mexican preschoolers with multiple micronutrient deficiencies. Am J Clin Nutr 71, 1485-1494. . 2002. Iron supplementation: Scientific issues concerning efficacy and implications for research and program. J Nutr 132, 813-819.

Angeles-Agdeppa I, Schultink W, Sastroamidjojo S, Gross R, \& Karyadi D. 1997. Weekly micronutrient supplementation to build iron stores in female Indonesian adolescents. Am J Clin Nutr $66,177-183$.

Briawan D. 2008. Efikasi Suplementasi Besi-Multivitamin terhadap Perbaikan Status Besi Remaja Wanita [disertasi]. Sekolah Pasca Sarjana, Institut Pertanian Bogor, Bogor.

[Depkes] Departemen Kesehatan. 2005. Pedoman Umum Gizi Seimbang (PUGS). Direktorat Jenderal Pembinaan Kesehatan Masyarakat, Direktorat Bina Gizi Masyarakat, Jakarta.

[Depkes] Departemen Kesehatan. 2008. Laporan Hasil Riset Kesehatan Dasar (Riskesdas) 2007. Badan Penelitian dan Pengembangan Kesehatan, Departemen Kesehatan RI, Jakarta.

Dwiriani CM. 2012. Pengaruh Pemberian Zat Multi Gizi Mikro dan Pendidikan Gizi terhadap Peri- laku Makan dan Status Besi Remaja Siswi SMP [disertasi]. Sekolah Pasca Sarjana, Institut Pertanian Bogor, Bogor.

Gera T, Sachdev HPS, \& Nestel P. 2008. Effect of combining multiple micronutrients with iron supplementation on $\mathrm{Hb}$ response in children: systematic review of randomized controlled trials. Public Health Nutrition 12(6), 756773.

Gibson RS. 2005. Principles of Nutritional Assessment. Oxford University Press, New York.

Haas JD \& Brownlie T. 2001. Iron deficiency and reduced work capacity: a critical review of the research to determine a causal relationship. J Nutr 131, 676S-690S.

Hyder SMZ et al. 2007. A multiple-micronutrientfortified beverage affects hemoglobin, iron, and vitamin A status and growth in adolescent girls in rural Bangladesh. J Nutr 137, 21472153.

Kanani SJ \& Poojara RH. 2000. Supplementation with iron and folic acid enhances growth in adolesent indian girls. J Nutr 130, 452S-455S.

Khatib LA et al. 2005. Folate deficiency is associated with nutritional anaemia in Lebanese women of childbearing age. Public Health Nutrition 9(7), 921-927.

Marcia N et al. 2010. Nutrition Therapy and Pathophysiology. Second edition. Wadsworth Cengage Learning, USA.

Soekarjo D et al. 2004. Effectivenes of weekly vita$\min \mathrm{A}(10.000 \mathrm{IU})$ and iron (60 mg) supplementation for adolescent boys and girls through schools in rural and urban East Java, Indonesia. Eur J Clin Nutr 58, 927-937.

WHO [World Health Organization]. 2008. WHO Global Database on Anemia. www.who.int [15 April 2012].

WNPG [Widyakarya Nasional Pangan dan Gizi]. 2004. Ketahanan Pangan dan Gizi di Era Otonomi Daerah dan Globalisasi. LIPI, Jakarta.

Tee ES et al. 1999. School-administered weekly iron-folate supplements improve hemoglobin and ferritin concentrations in Malaysian adolescent girls. Am J Clin Nutr 69, 1249-1256.

Zavaleta N, Respicio G, \& Garcia T. 2000. Efficacy and acceptability of two iron supplementation schedules adolescent school girls in Lima, Peru. J Nutr 130, 462S-464S. 